\title{
A review of the public sector substance use disorder treatment and prevention systems in Kenya
}

Florence Jaguga* (D) and Edith Kwobah

\begin{abstract}
Background: The burden of substance use disorders in sub-Saharan Africa has been projected to increase by an estimated $130 \%$ by 2050 . Despite this, little is known about the substance use disorder treatment and prevention systems in the region.
\end{abstract}

Objectives: The objective of this review is to describe the public sector substance use disorder treatment and prevention systems in Kenya guided by the World Health Organization health systems framework model, with the aim of informing decision-making.

Methods: We reviewed official government documents obtained from hand-searching the websites of relevant governmental organizations including: Ministry of Health, National Authority for the Campaign Against Alcohol and Drug Abuse, Parliament of Kenya, Ministry of Treasury \& National Planning, National Law Reporting Council, Kenya National Bureau of Statistics, the National Non-Governmental Organization (NGO) Coordination Board and the 47 County Governments. We augmented those searches with official documents that the authors were aware of by virtue of being practitioners in the field. Draft and retired documents were excluded. The findings of the search are presented as a narrative review.

Discussion: The Mental Health Act 1989, the main legislative framework governing substance use disorder treatment and prevention, focuses on institutional care only. While there are only three public health facilities offering substance use disorder treatment in Kenya, several non-public sector actors are involved in SUD treatment and prevention activities. Unfortunately, there is limited cross-sector collaboration. The Ministry of Health has no specific budget for substance use disorder treatment and prevention, while the National Authority for the Campaign Against Alcohol and Drug Abuse has an annual resource gap of about US\$ 5,000,000. The substance use disorder workforce in Kenya has not been characterized.

Conclusion: We propose five key strategies for strengthening substance use disorder treatment and prevention systems in Kenya including: (1) Enactment of the Mental Health (Amendment) bill 2018. (2) Integration of substance use disorder treatment and prevention into primary health care to increase access to care. (3) Utilization of money from taxation of alcohol, tobacco and betting to increase funding for substance use disorder treatment and prevention. (4) Characterization of the substance use disorder workforce to inform planning. (5) Enhanced collaboration between the government and non-state actors in order to increase access to SUD treatment and prevention.

Keywords: Substance use disorder, Treatment, Prevention, Systems

* Correspondence: flokemboi@gmail.com

Moi Teaching \& Referral Hospital, P.O. BOX 3-30100, Eldoret, Kenya

(C) The Author(s). 2020 Open Access This article is licensed under a Creative Commons Attribution 4.0 International License, which permits use, sharing, adaptation, distribution and reproduction in any medium or format, as long as you give appropriate credit to the original author(s) and the source, provide a link to the Creative Commons licence, and indicate if changes were made. The images or other third party material in this article are included in the article's Creative Commons licence, unless indicated otherwise in a credit line to the material. If material is not included in the article's Creative Commons licence and your intended use is not permitted by statutory regulation or exceeds the permitted use, you will need to obtain permission directly from the copyright holder. To view a copy of this licence, visit http://creativecommons.org/licenses/by/4.0/ The Creative Commons Public Domain Dedication waiver (http://creativecommons.org/publicdomain/zero/1.0/) applies to the data made available in this article, unless otherwise stated in a credit line to the data. 


\section{Background}

The burden of substance use disorders (SUDs) in subSaharan Africa has been projected to increase by an estimated $130 \%$ by 2050 [1]. Despite this, SUD treatment and prevention systems in the region remain under-resourced [2] and the treatment gap is as high as $87 \%$ [3]. Untreated SUDs are a major public health problem. Globally, SUDs are the second leading cause of disability among the mental disorders with 31,052,000 (25\%) Years Lived with Disability (YLD) attributed to them [4]. In Africa, the impact of problematic patterns of substance use is particularly high. For example in 2016, despite lower levels of alcohol consumption compared to elsewhere, the region had the highest age-standardized alcohol-attributable deaths and agestandardized alcohol-attributable Disability Adjusted Life Years (DALYs) (70.6 deaths per 100,000 people and 3043.7 per 100,000 people respectively) [5]. Further compounding this situation, is the fact that SUDs are associated with social costs as high as I\$ 800 per head [6], emanating from their impact on productivity, crime and health systems [7]. In sub-Saharan Africa where the burden of SUDs is high and countries are struggling to end poverty, it is important that governments place priority on strengthening their SUD treatment and prevention systems.

The World Health Organization (WHO) defines health systems strengthening as the process of improving the six health system building blocks namely service delivery, workforce, health information, medical products, financing and governance in order to achieve optimal health outcomes [8]. A well-functioning health system is therefore one that provides services that are safe, accessible and of quality; has a competent workforce that is sufficient in number; produces and disseminates health information in a timely manner; provides essential medication that is affordable; allocates adequate funds to health and finally is guided by strategic policies [8]. In Kenya, the need for an effective SUD treatment and prevention system is pressing. Over $10 \%$ of Kenyans aged between 15 and 65 years have an alcohol use disorder, with most of them (60\%) having the severe form [9]. In fact, the country has one of the highest total DALYs $(54,000)$ from alcohol use disorders in Africa [10]. Moreover, early onset substance use is a significant problem. In 2019, one in five adolescents were reported to have ever used at least one substance in their lifetime [11]. In that survey, the median age of onset was 11 years [11] and considerably lower than that (1619 years) reported elsewhere in the world [12]. Among both adults and adolescents in Kenya, substance use has been linked to risky sexual behavior $[11,12]$ which is a major driver of Human Immunodeficiency Virus (HIV) transmission in Kenya [13].

Unfortunately, the existing SUD treatment and prevention systems in Kenya are inadequate. The main legislative framework governing SUD treatment and prevention, the
Mental Health Act 1989 [14] is outdated and focuses on institutional care. Three out of over 5000 government run health facilities, deliver treatment for SUDs [15]. Moreover, the Ministry of Health (MOH) has no separate budget for SUD treatment and prevention. The objectives of this review are: (i) to provide an overview of the current state of public sector SUD treatment and prevention systems in Kenya guided by the WHO health systems framework. Prior literature examining the subject in subSaharan Africa is scarce and has mainly focused on select health system components $[2,16]$ (ii) to suggest recommendations for improvement. Such information could be useful in guiding the strengthening of SUD treatment and prevention systems in Kenya in line with Vision 2030, the country's long-term development blueprint [17], and target 3.5 of the Sustainable Development Goals (SDGs) [18].

\section{Methods}

Since our aim was to describe the public sector SUD treatment and prevention systems, we reviewed official government documents. We hand-searched the websites of relevant governmental organizations for documents and web pages that had content on SUD treatment and prevention. The organizations whose websites were searched include: $\mathrm{MOH}$, National Authority for the Campaign against Alcohol and Drug Abuse (NACA DA), Parliament of Kenya, National Council for Law Reporting, Kenya National Bureau of Statistics (KNBS), National Non-Governmental Organization (NGO) Coordination Board, each of the 47 County Governments. ${ }^{1}$ We excluded draft documents and those that had been replaced by newer versions. We augmented documents obtained from the searches with those that the authors were aware of by virtue of being practitioners in the mental health field. We reviewed a total of 40 documents (Table 1). The findings of the search are presented as a narrative review.

\section{Legislation \& policy governing SUD treatment and prevention in Kenya}

The Vision 2030 [17], Kenya's overall national development policy framework, recognizes SUDs as barriers to the attainment of national transformation, education, gender equality and the well-being of youth and other vulnerable populations. In doing so, the policy requires that the government implements projects and programs to mitigate the harmful impact of SUDs.

Unfortunately, the Mental Health Act, 1989 [14] which provides the main legal framework for addressing SUD treatment and prevention in Kenya is outdated and not

\footnotetext{
${ }^{1}$ Kenya promulgated a new constitution in 2010, creating a decentralized system of government exercised at 2 levels i.e. the National government and 47 County governments. Each level has its defined roles and responsibilities [19].
} 
Table 1 Documents included in this review

\begin{tabular}{|c|c|}
\hline Author & Document \& Year \\
\hline \multirow[t]{5}{*}{ National Law Reporting Council } & Mental Health Act 1989 [14] \\
\hline & Alcoholic Drinks Control Act [20] \\
\hline & Narcotic Drugs and Psychotropic Substances Act [21] \\
\hline & Health Act 2017 [22] \\
\hline & Tobacco Control Act 2007 [23] \\
\hline \multirow[t]{3}{*}{ NACADA } & NACADA Strategic Plan 2019-2022 [24] \\
\hline & $\begin{array}{l}\text { Knowledge Attitude Practices of Christian Faith Based Organizations on Alcohol and Drug } \\
\text { Abuse [25] }\end{array}$ \\
\hline & $\begin{array}{l}\text { Effectiveness of Community Based Interventions to Mitigate Harmful Alcohol Use in Murang'a } \\
\text { East District [26] }\end{array}$ \\
\hline \multirow[t]{2}{*}{ Parliament of Kenya } & National Programs Based Budget 2019/2020 [27] \\
\hline & Mental Health (Amendment) Bill 2018 [28] \\
\hline $\begin{array}{l}\text { National Non-Governmental Organization Co- } \\
\text { ordination Board }\end{array}$ & Annual NGO Sector Report 2018/19 [29] \\
\hline Ministry National Treasury \& Planning & Vision 2030 Third Medium term Plan 2018-2022 [17] \\
\hline \multirow[t]{4}{*}{ Ministry of Health } & Kenya Essential Medicines List 2019 [30] \\
\hline & The Kenya Mental Health Policy 2015-2030 [31] \\
\hline & The National Protocol for Treatment of Substance Use Disorders in Kenya 2017 [32] \\
\hline & Health Indicator and Standard Operating Procedures Manual 3rd Edition, 2017 [33] \\
\hline \multirow[t]{3}{*}{ Kenya National Bureau of Statistics } & Kenya Demographic Health Survey 2014 [34] \\
\hline & Kenya STEPwise Survey for Non-communicable Diseases Risk Factors 2015 Report [35] \\
\hline & Global Adult Tobacco Survey 2014 [36] \\
\hline Embu County Government & Embu County MTEFa Programs Based Budget 2019/2020 [37] \\
\hline Kisii County Government & Kisii County Programs Based Budget 2019/2020 [38] \\
\hline Bomet County Government & Bomet County MTEF Programs Based Budget 2019/2020 [39] \\
\hline Kajiado County Government & Kajiado County Programs Based Budget 2019/20 [40] \\
\hline Kericho County Government & Kericho County Programs Based Budget 2019/2020 [41] \\
\hline Laikipia County Government & Laikipia County Programs Based Budget 2019/2020 [42] \\
\hline West Pokot County Government & West Pokot County Programs Based Budget 2019/2020 [43] \\
\hline Elgeyo Marakwet Government & Elgeyo Marakwet County Programs Based Budget 2019/2020 [44] \\
\hline Turkana County Government & Turkana County Programs Based Budget 2019/2020 [45] \\
\hline Makueni Government & Makueni County Programs Based Budget 2019/2020 [46] \\
\hline Machakos County Government & Machakos County Programs Based Budget 2019/2020 [47] \\
\hline Kakamega County Government & Kakamega County Programs Based Budget 2019/2020 [48] \\
\hline Mombasa County Government & Mombasa County Programs Based Budget 2019/2020 [49] \\
\hline Vihiga County Government & Vihiga County MTEF Programs Based Budget 2018/19-2020/21 [50] \\
\hline Kwale County Government & Kwale County Programs Based Budget 2018/19-2020/21 [51] \\
\hline Nyeri County Government & Nyeri County Programs Based Budgets 2019/20 [52] \\
\hline Lamu County Government & Lamu County MTEF Programs Based Budget 2017/18-2019/20 [53] \\
\hline Samburu County Government & Samburu County Programs Based Budgets2019/2020 [54] \\
\hline Wajir County Government & Wajir County Programs Based Budget 2019/2020 [55] \\
\hline Kilifi County Government & Kilifi County Programs Based Budget 2019/2020 [56] \\
\hline Tharaka-Nithi County Government & Tharaka-Nithi County Programs Based Budget 2019/2020 [57] \\
\hline
\end{tabular}


in line with Vision 2030. The act focuses on institutional care and has no provisions mandating the delivery of preventive, rehabilitative or community based care. Further, the act does not address critical issues such as access to care, stigma, discrimination and the rights of persons who use mental health and SUD services [58]. Moreover, the act is at odds with the current Constitution of Kenya, 2010 which devolves health functions to the county governments [19]. The Mental Health Act, 1989 [14] however recognizes a SUD as a mental disorder in line with the current understanding of these disorders as health problems [59].

The proposed Mental Health (Amendment) Bill, 2018 [28], currently awaiting its first reading in parliament seeks to overhaul the Mental Health Act, 1989 [14]. In addressing the limitations of this Act, the bill requires that the government provides community based care. It directs that treatment and prevention of mental health and SUDs includes prevention, early intervention, rehabilitation and follow-up. The bill additionally contains provisions that mandate the government to ensure access to care, to promote non-discriminatory practices by insurance providers, and to ensure that the rights of persons with mental health conditions and SUDs are upheld. In line with the Constitution of Kenya, 2010 [19], the bill delineates the roles and responsibilities of the National and County Governments in mental health and SUD service delivery.

Importantly, this bill is aligned with Vision 2030 [17], and guidelines for the delivery of SUD services presented in the Kenya Mental Health Policy 2015-2030 [31]. The Kenya Mental Health Policy 2015-2030 recommends that in treating SUDs, services should be evidence-based, comprehensive and universally accessible. The policy recommends the establishment of preventive programs, community based services, and the incorporation of psychosocial rehabilitation into SUD treatment. In order to ensure accessibility, the policy recommends that treatment for SUDs be provided at all levels of the health care system [31]. Upon enactment and implementation, the Mental Health (Amendment) Bill, 2018 [28] will therefore be useful in streamlining and transforming SUD treatment and prevention in Kenya.

Other than the Mental Health Act 1989, several other laws contain provisions that seek to address SUD treatment and prevention in Kenya. The Health Act, 2017 [22], The Tobacco Control Act, 2007 [23], The Alcoholic Drinks control Act, 2010 [20] and The Narcotic Drugs E Psychotropic Substances (Control) Act, 1994 [21] all mandate the government to educate the public on the adverse health consequences of substances. They further require that the Ministry of Education and the $\mathrm{MOH}$ integrate instruction on the health consequences posed by substances into syllabuses and healthcare respectively.
The Alcoholic Drinks Control Act, 2010 [20] and the Narcotic Drugs \& Psychotropic Substances, Act 1994 [21] specifically mandate that the government provides rehabilitation programs for persons dependent on alcohol and illegal substances respectively. The Narcotic Drugs E Psychotropic Substances Act, 1994 [21] provides for committal to rehabilitation for those found in possession if the court is satisfied that the person arrested is addicted and was in possession for his own personal consumption. Both Acts require that the government sets up a fund consisting of monies obtained from licensing fees, fines and grants for purposes of SUD treatment and prevention. Currently part of the funds obtained under the Alcoholic Drinks Control Act 2010 [20] are allocated to the NACA DA and to civil society organizations conducting SUD programs to facilitate their operations $[24,60]$.

Unfortunately, The Alcoholic Drinks Control Act 2010 [20] and the Narcotic Drugs \& Psychotropic Substances Act 1994 [21] mandate punitive measures for substance use and possessions, and lack a human rights approach. Persons who use substances therefore frequently get incarcerated and exposed to harassment, discrimination and human rights abuses by law enforcement [61]. In a joint statement in 2017, the United Nations (UN) and the WHO recommended the reviewing and repealing of laws that criminalize substance use or possession of substances for personal use [62]. This has not yet been done in Kenya.

Workplace policies on SUD treatment and prevention are an integral part of SUD management at the institutional level and are an International Labor Organization (ILO) requirement [63]. Such policies which offer guidelines on the strategies and measures to be undertaken in order to mitigate the harmful impact of SUDs in the workplace, are currently not mandated by existing local legislation. The NACADA has however published guidelines for the development of workplace policies on SUD treatment and prevention that organizations can refer to in preparing their own policies [64].

\section{SUD treatment and prevention: service delivery}

SUD treatment and prevention services are delivered within the health sector by the $\mathrm{MOH}$, and the County Government Departments of Health; and outside the health sector by the NACADA and various County Government Departments.

\section{Health sector SUD service delivery}

The key responsibilities of the $\mathrm{MOH}$ include developing health policies, managing five national referral health facilities as well as oversight of service delivery at the County level. The County Departments of Health are in turn tasked with the delivery of facility and community based health care at the county level, and report to the $\mathrm{MOH}$ [65]. In realization of its mandates, the $\mathrm{MOH}$ 
through its Division of Mental Health and Substance Abuse Management, has successfully spearheaded the development of a treatment protocol for SUDs [32] and the Kenya Mental Health Policy 2015-2030 [31]. The $\mathrm{MOH}$ additionally supports and co-ordinates opiate substitution therapy and needle exchange programs as HIV prevention interventions through its National AIDS and STI's Control Programme. This is largely done in collaboration with NGOs $[66,67]$.

The health sector SUD services however remain scarce and inaccessible. Out of 5800 health facilities run by the $\mathrm{MOH}$ and County Departments of Health in Kenya, only three offer SUD rehabilitation services and all are located in urban centers [15]. Further, only three County Health Departments had planned programs relating to SUD treatment and prevention for the 2019/2020 financial year (Table 2). The opiate substitution therapy clinics also located in urban areas, are heavily supported by donor funding [67] and their sustainability therefore remains a challenge.

\section{Role of the NACADA}

The NACADA is a State Corporation in the Ministry of Interior and Coordination of National Government. Its role centers on SUD prevention [68]. The NACADA therefore runs a series of public education programs often in collaboration with other public and private organizations [68]. The authority which has one national and eight regional offices across the country, recently piloted a life skills training program in 81 primary schools across the country in order to curb early substance use [24]. Other than public education, the NACA DA is responsible for licensing and regulating SUD rehabilitation facilities [69].

\section{Other County departments}

In the $2019 / 2020$ financial year, $70 \%$ of the Counties had their SUD programs under various departments including Public administration, Education, Social services and Youth empowerment (Table 2). It has been recommended that SUD treatment and prevention be integrated into mainstream health care as this ensures concurrent management of comorbidities, increased access to services as well as adequate quality of care [70].

\section{Role of non-state actors}

In order to ensure improved access to SUD treatment and prevention, as well as achieve efficiencies in service delivery, there is need for collaborative and complementary work between the government and non-state actors. Based on data from the NACADA, there are more than 80 accredited private-for-profit SUD rehabilitation facilities across the country [15]. Private sector healthcare is however costly and therefore inaccessible for a majority

Table 2 County Government SUD treatment and prevention programs

\begin{tabular}{|c|c|c|c|c|}
\hline & County & $\begin{array}{l}\text { Program description } \\
\text { (Based on Programs Based Budget 2019/2020) }\end{array}$ & County Departments supervising the program & $\begin{array}{l}\text { Amount } \\
\text { allocated (US\$) }\end{array}$ \\
\hline 1. & $\begin{array}{l}\text { Kakamega } \\
{[48]}\end{array}$ & $\begin{array}{l}\text { Alcohol and drug abuse Rehabilitation program } \\
\text { (construction and purchase of equipment) }\end{array}$ & Department of Public Service and administration & $54,905^{\mathrm{a}}$ \\
\hline 2. & Mombasa [49] & $\begin{array}{l}\text { Control of drug and substance abuse, Medically } \\
\text { Assisted Therapy }\end{array}$ & Department of Health services & $225,884^{b}$ \\
\hline 3. & Samburu [54] & Increase awareness on alcohol and drug abuse & Department of Health services & $3,442,039^{c}$ \\
\hline 4. & Kwale [51] & $\begin{array}{l}\text { Management of drug and substance abuse } \\
\text { rehabilitation centre }\end{array}$ & Department of Social services and talent management & 32,366 \\
\hline 5. & Kilifi [56] & $\begin{array}{l}\text { Campaign and sensitization against drug/substance } \\
\text { abuse }\end{array}$ & Department of Gender, Culture, Social Services and Sports & $40,000^{d}$ \\
\hline 6. & Embu [37] & Rehabilitation of persons with SUDs & $\begin{array}{l}\text { Department of Youth empowerment, gender, children, } \\
\text { culture and social services }\end{array}$ & 81,061 \\
\hline 7. & Machakos [47] & Create awareness on SUDs & Department of Tourism, culture, Youth, Sports & 13,308 \\
\hline 8. & Makueni [46] & Anti-drug \& substance abuse program & $\begin{array}{l}\text { Department of Education, Youth, Sports, and Information } \\
\text { Communication and Technology }\end{array}$ & $300,000^{e}$ \\
\hline 9. & Turkana [45] & $\begin{array}{l}\text { Rehabilitation and treatment for alcohol and drug } \\
\text { abuse; Public education advocacy and awareness }\end{array}$ & Department of Health services and sanitation & 19,000 \\
\hline 10. & $\begin{array}{l}\text { Elgeyo } \\
\text { Marakwet [44] }\end{array}$ & Baseline survey on prevalence of alcohol use & Department of Public Administration and governance & $556,040^{f}$ \\
\hline
\end{tabular}

amount includes allocation for alcoholic drinks control

bamount includes allocation for family, maternal, adolescent and child health; Malaria; Tuberculosis treatment and prevention; HIV/AIDS treatment and prevention 'amount was allocated to 'preventive and promotive health services' with 'increasing awareness on alcohol and drug abuse' as one of the programs damount includes allocation for anti-radicalization, peace and security campaigns; youth talent identification; youth economic empowerment, campaign against teenage pregnancy and youth skills training

eamount includes allocation for sports development

amount includes allocation for inspection of alcoholic drinks outlets 
of Kenyans [71]. A number of NGOs are involved in SUD treatment and prevention activities. In the 2018/ 2019 financial year, 4\% of newly registered NGOs implemented projects on SUD treatment and prevention. During the same period, a $51 \%$ increase in utilization of funds on SUD programs was noted compared to the prior financial year, indicating growing NGO involvement in the field [29]. A lack of meaningful engagement has been reported in Kenya between the government on one hand and the private sector and NGOs on the other [29, 72].

The involvement of faith based organizations and community based organizations in delivering SUD prevention has been documented in Kenya [25, 26]. The activities of both types of organizations largely revolve around public education but also include economic empowerment for brewers of illicit alcohol and persons with SUDs. However, such organizations often lack adequate knowledge and finances necessary for implementing impactful interventions within their spheres of influence $[25,26]$.

Like elsewhere in the world [73], mutual self-help groups are a part of SUD treatment in Kenya. There are over 30 Alcoholics Anonymous groups spread across several major cities in the country [74]. Participation in mutual self-help groups has been shown to lead to reduced substance consumption as well as lessen the need for more costly specialized treatment services [73].

A number of opportunities exist for meaningful collaboration between the government and non-state actors in SUD treatment and prevention in Kenya: (i) Capacity building of faith based organizations, community based organizations and mutual self-help groups by the government in order to make them potential means for SUD treatment and prevention at the grassroots level. (ii) Accreditation of private SUD treatment facilities by the National Hospital Insurance Fund (NHIF) to increase access to specialized SUD treatment. Currently, only three private rehabilitation facilities are accredited [15].

\section{Government budgetary allocation to SUD treatment and prevention}

The MOH had no specific budgetary allocation for SUD treatment and prevention [27]. At the County level, only 10 out of 20 counties whose 2019/2020 budgets were available online had allocation to SUD treatment and prevention programs (Table 2). The exact amounts allocated to SUD programs were in most instances difficult to quantify since they had been lumped together with other programs. Where SUD programs had been budgeted for separately, allocations ranged from US\$ 13,000 to 80,000 per annum (Table 2). The NACADA receives funding from the government and from the Alcoholic Drinks Control Act fund totaling to about US\$ 5,000, 000 annually [24]. According to its 2019-2023 strategic plan the authority will require an average of US\$ 10,000 ,
000 annually to carry out its activities. This leaves the authority with an annual resource gap of about US\$ 5 , 000,000 [24].

The cost of interventions for alcohol use disorders has been estimated and could serve as a guide during planning. For example, public awareness campaigns to prevent harmful alcohol use have been approximated to cost US\$ $0.2-0.8$ per person in the population per annum, and that of brief interventions offered within the health sector US\$ $0.4-1.8$ per person in the population per annum [75]. Strategies to increase funding for SUD treatment and prevention have also been proposed. These include the use of money from taxation of legal substances and betting for SUD care. It has further been recommended that all financial resources for SUD care be pooled into a common fund to ensure efficient use [76]. Such strategies could be adopted in Kenya.

\section{SUD treatment and prevention: human resource}

Globally, the SUD treatment and prevention workforce is diverse comprising of peers, teachers, counselors, social workers and nurses $[15,70]$. Certification in SUD treatment and prevention has therefore been introduced as a way of standardizing care [77]. In Kenya, NACADA offers a certification course, the Basic Universal Treatment Curriculum Training Program for Addiction Professionals [69] Information on the number of certified counselors trained so far, their current placement, professional background and responsibilities was however not available. In order to make useful recommendations, the SUD workforce in Kenya needs to be characterized. Nonetheless, integration of SUD treatment and prevention into primary care has been shown to be cost-effective resulting in an estimated I\$ 3,000 per DALY saved [75]. It is therefore important that primary health care workers in Kenya receive training on SUD treatment and prevention and form the frontline SUD workforce.

\section{SUD treatment and prevention: information systems}

Kenya has a number of sources of information on substance use that could inform interventions. The KNBS in collaboration with various stakeholders conducts several national household surveys. The Kenya Demographic Health Survey collects data on the patterns of alcohol consumption among other health indicators and has been conducted twice so far (in 2003 and 2014) [34]. The Global Adult Tobacco Survey provides information on the patterns of tobacco use among persons 15 years and older [36] while the STEPwise survey for noncommunicable disease risk factors, collects information on alcohol and tobacco use among other risk factors [35]. The NACADA conducts nationwide general population surveys every 5 years on the status of substance use and SUDS. Data collected includes prevalence rates 
as well as information on knowledge, awareness and health consequences. The authority also conducts other surveys examining the burden and impact of substance use among specific populations on a need basis [78].

The $\mathrm{MOH}$ through its health sector indicator manual [33] provides guidelines for the minimum set of health indicators to be collected to facilitate planning. Four of these relate to SUDs: (i) percentage of adults who are heavy episodic drinkers (ii) number of planning entities (e.g. Counties) that have a SUD management plan (iii) proportion of population who smoke cigarettes or a pipe or use other tobacco products (iv) proportion of campaigns conducted to create awareness on tobacco cessation. The $\mathrm{MOH}$ relies on surveys conducted by the KNBS and data from County Governments and health facilities to monitor these indicators [33]. Data collected by health facilities have particularly been found to be of poor quality hence not beneficial for decision-making [79].

\section{SUD treatment and prevention: essential medicines}

The WHO recommends that at the minimum, health systems must have nicotine replacement therapy and methadone for the management of SUDs [80]. The Kenya Essential Medicine List (KEML) 2019 contains a wider range of drugs for the treatment of SUDs including Vitamin B, bupropion, buprenorphine, buprenorphine/naloxone, naltrexone, methadone and nicotine replacement therapy [30]. The availability of these drugs at the facility level is however problematic. An unpublished study conducted at the largest public mental health hospital in Kenya found that the facility had only $50 \%$ of the drugs listed in the essential medical list that was operational at the time. The authors also reported that stock outs were frequent with over half of the drugs being out of stock for 12 consecutive months [81].

\section{Limitations}

A limitation of this review is that it describes the SUD treatment and prevention systems in Kenya based on documents and information that was available online. Information unavailable on the internet such as some County government budgets and implementation levels of planned programs was therefore missed out. A future study obtaining data from key informant interviews and review of hard copies of government documents, and guided by a structured tool such as the World Health Organization-Assessment Instrument for Mental health Systems (WHO-AIMS) [82] could provide a more comprehensive description of the SUD treatment and prevention systems in Kenya.

\section{Conclusion}

The SUD treatment and prevention systems in Kenya are under-resourced. We propose five key strategies for strengthening SUD treatment and prevention systems in Kenya: (1) Enactment of the Mental Health (Amendment) bill 2018. (2) Integration of substance use disorder treatment and prevention into primary health care to increase access to care. (3) Utilization of money from taxation of alcohol, tobacco and betting to increase funding for substance use disorder treatment and prevention. (4) Characterization of the substance use disorder workforce to inform planning. (5) Enhanced collaboration between the government and non-state actors in order to increase access to SUD treatment and prevention.

\section{Abbreviations \\ AIDS: Acquired Immune Deficiency Syndrome; DALY: Disability Adjusted Life Year; HIV: Human Immunodeficiency Virus; I\$: International Dollar; \\ ILO: International Labor Organisation; KEML: Kenya Essential Medical List; KNBS: Kenya National Bureau of Statistics; MOH: Ministry of Health; \\ MTEF: Mid-Term Expenditure Framework; NACADA: National Authority for the Campaign Against Alcohol and drug Abuse; NGO: Non-Governmental Organization; NHIF: National Hospital Insurance Fund; STIs: Sexually \\ Transmitted Infections; SDG: Sustainable Development Goals; SUD: Substance use disorder; UN: United Nations; USS: United States Dollar; YLD: Years lived with Disability; WHO-AIMS: World Health Organization-Assessment Instru- ment for Mental health Systems; WHO: World Health Organization}

\section{Acknowledgements \\ Not applicable.}

\section{Authors' contributions}

FJ conceived the idea. FJ and EK identified the organizations involved in substance use disorder treatment and prevention. FJ and EK hand-searched the organization websites for relevant documents. FJ wrote the first draft of the manuscript. FJ and EK contributed to subsequent revisions of the first draft. All authors approved the final manuscript.

\section{Authors' information}

F.J. is a Psychiatrist and the Consultant In-charge of the Alcohol \& Drug Abuse Rehabilitation Unit at Moi Teaching \& Referral Hospital. She is also a National Executive Council Member of the Kenya Psychiatric Association. E.K. is Head of the Mental Health Department at Moi Teaching \& Referral Hospital.

\section{Funding}

There are no sources of funding to declare.

Availability of data and materials

Not applicable.

Ethics approval and consent to participate

Not applicable.

\section{Consent for publication}

Not applicable.

\section{Competing interests}

The authors declare that they have no competing interests.

Received: 1 May 2020 Accepted: 14 July 2020

Published online: 20 July 2020

\section{References}

1. Charlson FJ, Diminic S, Lund C, Degenhardt L, Whiteford HA. Mental and substance use disorders in sub-Saharan Africa: predictions of epidemiological changes and mental health workforce requirements for the next 40 years. PLoS One. 2014;9(10). https://doi.org/10.1371/journal.pone. 0110208.

2. Salwan J, Katz CL. A review of substance [corrected] use disorder treatment in developing world communities [published correction appears in Ann 
glob health. 2014 Sep-Oct;80(5):426]. Ann Glob Health. 2014;80(2):115-21. https://doi.org/10.1016/j.aogh.2014.04.010.

3. Zewdu, S., Hanlon, C., Fekadu, A. et al. Treatment gap, help-seeking, stigma and magnitude of alcohol use disorder in rural Ethiopia. Subst Abuse Treat Prev Policy.2019;14(4). https://doi.org/https://doi.org/10. 1186/s13011-019-0192-7.

4. GBD 2017 Disease and Injury Incidence and Prevalence Collaborators. Global, regional, and national incidence, prevalence, and years lived with disability for 354 diseases and injuries for 195 countries and territories, 1990-2017: a systematic analysis for the Global Burden of Disease Study 2017 [published correction appears in Lancet. 2019 Jun 22;393(10190):e44]. Lancet. 2018;392(10159):1789-858. https://doi.org/10.1016/S01406736(18)32279-7.

5. Hammer JH, Parent MC, Spiker DA, World Health Organization. Global status report on alcohol and health 2018. https:/apps.who.int/iris/bitstream/handle/1 0665/274603/9789241565639-eng.pdf?ua=1. Accessed 28 April 2020.

6. Rehm J, Mathers C, Popova S, Thavorncharoensap M, Teerawattananon Y, Patra J. Global burden of disease and injury and economic cost attributable to alcohol use and alcohol-use disorders. Lancet. 2009;373(9682):2223-33. https://doi.org/10.1016/50140-6736(09)60746-7.

7. International Narcotics Control Board. Chapter 1: economic consequences of drug abuse. 2013. https://www.incb.org/documents/ Publications/AnnualReports/AR2013/English/AR_2013_E_Chapter_I.pdf. Accessed 30 April 2020.

8. World Health Organization (WHO). Everybody's business: strengthening health systems to improve health outcomes: WHO's framework for action. 2007. https://www.who.int/healthsystems/strategy/everybodys_business.pdf. Accessed 30 April 2020.

9. National Authority for the Campaign Against alcohol and Drug Abuse. Rapid Situation Assessment of Drugs abd Substance Abuse in Kenya. 2017. https://nacada.go.ke/sites/default/files/2019-10/National\%20ADA\%2 OSurvey\%20Report\%202017_2_2.pdf. Accessed 30 April 2020.

10. World Health Organization. Alcohol and drug use disorders: Global health estimates. 2017. http://www.who.int/substance_abuse/activities/fadab/msb_ adab_2017_GHE_23June2017.pdf. Accessed 30 April 2020.

11. National Authority for the Campaign Against alcohol and Drug Abuse, Kenya Institute for Public Policy Research and Analysis. Status of Drugs and Substance Abuse among Primary School Pupils in Kenya. 2019. https:// nacada.go.ke/sites/default/files/2019-10/Report\%20on\%20the\%20Status\%2 0of\%20Drugs\%20and\%20Substance\%20Abuse\%20among\%20Primary\%2 0School\%20Pupils\%20in\%20Kenya.pdf. Accessed 30 April 2020.

12. Degenhardt L, Stockings E, Patton G, Hall WD, Lynskey M. The increasing global health priority of substance use in young people. Lancet Psychiatry. 2016;3(3):251-64. https://doi.org/10.1016/52215-0366(15)00508-8.

13. National Aids Control Council. Kenya HIV prevention response and modes of transmission analysis. 2009. https://icop.or.ke/wp-content/uploads/2016/ 09/KenyaMOT-2009.pdf. Accessed 4 April 2020.

14. Republic of Kenya. Mental Health Act. 1989. http://kenyalaw.org:8181/exist/ kenyalex/actview.xql?actid=CAP.\%20248. Accessed 30 April 2020.

15. National Authority for Campaign against Alcohol and Drug Abuse. [Internet]. https://nacada.go.ke/rehabilitation-centers. Accesssed 30 April 2020.

16. Sodano R, Watson DW, Rataemane S, Rataemane L, Ntthe N, Rawson R. The substance Abuse treatment workforce of South Africa. Int J Ment Heal Addict. 2010;8(4):608-15. https://doi.org/10.1007/s11469-009-9245-x.

17. Republic of Kenya. The National Treasury and Planning. Third Medium Term Plan 2018-2022. Kenya Vision 2030. https://planning.go.ke/wp-content/ uploads/2018/12/THIRD-MEDIUM-TERM-PLAN-2018-2022.pdf. Accessed 20 June 2020.

18. United Nations. Transforming Our World: The 2030 Agenda for Sustainable Development. https://sustainabledevelopment.un.org/content/ documents/21252030\%20Agenda\%20for\%20Sustainable\%2 ODevelopment\%20web.pdf. Accessed 20 June 2020.

19. Republic of Kenya. Constitution of Kenya. 2010. http://www.kenyalaw.org:81 81/exist/kenyalex/actview.xql?actid=Const2010. Accessed on 30 April 2020.

20. Republic of Kenya. Alcoholic Drinks Control Act. 2012. http://kenyalaw.org:81 81/exist/kenyalex/actview.xql?actid=No.\%204\%20of\%202010.

21. Republic of Kenya. Narcotic drugs and psychotropic substances Act 1994. http://kenyalaw.org/kl/fileadmin/pdfdownloads/Acts/ NarcoticDrugsandPsychotropicSubstances_Control_Act_Cap245.pdf. Accessed 30 April 2020.
22. Republic of Kenya. Kenya Health Act. 2017. http://kenyalaw.org:8181/ exist/kenyalex/actview.xql?actid=No.\%2021\%20of\%202017. Accessed 30 April 2020.

23. Republic of Kenya. Tobacco Control Act. 2007. http://kenyalaw.org:8181/exist/ kenyalex/actview.xq|?actid=No.\%204\%20of\%202007. Accessed 30 April 2020.

24. National Authority for the Campaign Against Alcohol and Drug Abuse. Strategic Plan 2019-2022. 2019. https://nacada.go.ke/sites/default/files/2 019-11/NACADA\%20STRATEGIC\%20PLAN\%202019-23.pdf. Accessed 30 April 2020.

25. Nyamongo IK. National campaign against alcohol and drug Abuse. Knowledge Attitude Practices of Christian Faith Based Organizations on Alcohol and Drug Abuse https://nacada.go.ke/sites/default/files/2019-10/ knowledge $\% 20$ attitudes\%20and\%20practices\%20of\%20christian\%20fbos\%2 0on\%20alcohol\%20and\%20drug\%20abuse.pdf. Accessed 20 June 2020.

26. Kariuki M, Oteyo J. National Campaign against Alcohol and drug Abuse. Effectiveness of Community Based Interventions to Mitigate Harmful Alcohol Use in Murang'a East District 2013. https:/nacada.go.ke/sites/ default/files/2019-10/effectiveness\%20of\%20community\%20based\%2 Ointerventions\%20to\%20mitigate\%20harmful\%20alcohol\%20use\%20in\%2 Omuranga\%20east\%20district.pdf. Accessed 20 June 2020.

27. Republic of Kenya. 2019/2020 Programme Based Budget of the National Government of Kenya 2019. http://www.parliament.go.ke/sites/default/ files/2019-05/Programme\%20Based\%20Budget\%20for\%20the\%20FY\%20201 9\%20-\%202020.pdf. Accessed 30 April 2020.

28. Republic of Kenya. Mental Health (Amendment) Bill. 2018. http://www. parliament.go.ke/sites/default/files/2018-12/Mental\%20Health\%20\%2 8Amendment\%29\%20Bill\%2C\%202018.pdf. Accessed 30 April 2020.

29. Non-Governmental Organization Co-ordination Board. Annual NGO sector report 2018/19. 2019. https://ngobureau.go.ke/wp-content/uploads/2020/ 02/ANNUAL-NGO-SECTOR-REPORT-2018-2019.pdf. Accessed 20 June 2020.

30. Ministry of Health. Kenya Essential Medicine List. 2019. http://www.health. go.ke/wp-content/uploads/2020/03/Kenya-Essential-Medicines-List-2019.pdf. Accessed 29 April 2020.

31. Ministry of Health. Kenya mental health policy 2015-2030. 2015. http:// publications.universalhealth2030.org/uploads/Kenya-Mental-Health-Policy. pdf. Accessed 30 April 2020.

32. Ministry of Health. The national protocol for treatment of substance use disorders in Kenya. 2017. https://www.afro.who.int/sites/default/files/201709/The\%20National\%20Protocol\%20for\%20treatments\%2014\%2007\%202017. pdf. Accessed 30 April 2020.

33. Ministry of Health. Health Sector Indicator and Standard Operating Procedures Manual Third edition. 2017. http://healthgarissa.go.ke/ downloads/Health\%20sector\%20indicators\%20and\%20SOPs\%20manual\%2 Ofinal\%20\%20Aug\%202017.pdf. Accessed 30 April 2020.

34. Kenya National Bureau of Statistics. Kenya Demographic Health Survey. 2014. Available from: https://www.knbs.or.ke/?page_id=3142. Accessed 21 June 2020.

35. Kenya National Bureau of Statistics. Kenya STEPwise Survey for Noncommunicable Diseases Risk Factors Report. 2015. Available from: https:// www.knbs.or.ke/?page_id=3142. Accessed 21 June 2020.

36. Kenya National Bureau of Statistics. Global Adult Tobacco Survey. 2014. Available from: https:/www.knbs.or.ke/?page_id=3142. Accessed 21 June 2020.

37. County Government of Embu. Programme Based Budget for Financial Year 2019/2020. 2019. https://embuassembly.go.ke/budget-estimates-2019-2020/. Accessed 23 April 2020

38. County Government of Kisii. Programme Based Budget for Financial Year 2019/2020. 2019. https://www.kisii.go.ke/index.php/county-downloads. Accessed 17 July 2020

39. County Government of Bomet. Programme Based Budget for Financial Year 2019/2020. 2019. https://www.bometassembly.go.ke/upload/PBB\%20FOR\%2 OFY\%202019.2020-1.pdf. Accessed 23 April 2020.

40. County Government Kajiado. Programme Based Budget for Financial Year 2019/2020. 2019. https://www.kajiado.go.ke/media-centre/downloads/. Accessed 23 April 2020.

41. County Government of Kericho. Programme Based Budget for Financial Year 2019/2020. 2019. https://www.kericho.go.ke/downloads/0000997Kericho\%20Approved\%20PBB\%20Complete\%20doc\%202019-2020.pdf. Accessed 23 April 2020

42. County Government of Laikipia. Programme Based Budget for Financial Year 2019/2020. 2019. https://laikipia.go.ke/resource/budget-estimates-2019-2020. Accessed 23 April 2020. 
43. County Government Of West Pokot. Programme Based Budget for Financial Year 2019/2020. 2019. https://kapenguriamunicipality.co.ke/wp-content/ uploads/2019/09/WPC-FY-19-20-PPB-ESTIMATES.pdf. Accessed 23 April 2020.

44. County Government Of Elgeyo Marakwet. Programme Based Budget for Financial Year 2019/2020. 2019. https://elgeyomarakwet.go.ke/mdocsposts/2019-20-fy-program-based-budget-approved/. Accessed 23 April 2020.

45. County Government of Turkana. Programme Based Budget for Financial Year 2019/2020. 2019. https://urkana.go.ke/wp-content/uploads/2019/09/ Turkana-County-Budget-FY-2019_20.pdf. Accessed 23 April 2020.

46. County Government of Makueni. Programme Based Budget for Financial Year 2019/2020. 2019. https://makueni.go.ke/downloads/. Accessed 23 April 2020.

47. County Government Of Machakos. Programme based budget for financial year 2019/2020. 2019. https://machakosgovernment.co.ke/documents/. Accessed 23 April 2020.

48. County Government Of Kakamega. Programme based budget for financial year 2019/2020. 2019. https://kakamega.go.ke/county-budget-documents/. Accessed 23 April 2020.

49. County Government Of Mombasa. Programme based budget for financial year 2019/2020. 2019. http://www.mombasaassembly.go.ke/wp-content/ uploads/2019/06/Msa-PBB-19-20-Final-June.pdf. Accessed 23 April 2020.

50. County Government Of Vihiga. Medium term expenditure frame work Programme based budget for financial year 2018/19-2020/21. 2018. https:// vihiga.go.ke/documents/PBB\%20Budget\%20Appropriation\%202018-19.pdf. Accessed 23 April 2020.

51. County Government Of Kwale. Medium term expenditure frame work Programme based budget for financial year 2018/19-2020/21. 2018. https:// kwalecountygov.com/kwale/downloadapp/index.php/cdownloads/send/11cbp-2019/9-ppb-2019-2021. Accessed 23 April 2020.

52. County Government Of Nyeri. Programme based budget for financial year 2019/2020. 2019. https://www.nyeriassembly.go.ke/budget-documents/. Accessed 23 April 2020.

53. County Government Of Lamu Medium Term Expenditure Framework Programme Based Budget for Financial Year 2017/18-2019/20. http://lamu. go.ke/wp-content/uploads/2018/11/BUDGET_2017_8-_APRIL_final.pdf. Accessed 23 April 2020.

54. County Government Of Samburu Programme Based Budget for Financial Year 2019/2020. 2019. https://www.samburu.go.ke/downloads/. Accessed on 23rd April 2020.

55. County Government Of Wajir. Programme based budget for financial year 2019/2020. 2019. https://www.wajir.go.ke/UserSiteFiles/Municipality/ Budget\%20Estimates\%202019-2020.pdf. Accessed 23 April 2020.

56. County Government Of Kilifi. Programme based budget for financial year 2019/2020. 2019. https://www.kilifi.go.ke/library.php?com=5\&com2=15 0\&com3=155\&com4=\#.XpxsRZIRU2w. Accessed 23 April 2020.

57. County Government of Tharaka-Nithi. Programme Based Budget for Financial Year 2019/2020. 2019. https://tharakanithi.go.ke/budget/. Accessed 23 April 2020.

58. Funk M, Drew MN. WHO Checklist on Mental Health Legislation Introduction and how to use this checklist. :119-54. http:// wellbeingfoundation.com/ECT_Evidence/ECT_Documents_Wellbeing_F/ WHOLegislationChecklist.pdf. Accessed 4 April 2020.

59. Leyton M. Are addictions diseases or choices? [published correction appears in J Psychiatry Neurosci. 2013 Nov;38(6):387] [published correction appears in J Psychiatry Neurosci. 2013 Sep;38(5):305]. J Psychiatry Neurosci. 2013; 38(4):219-21. https://doi.org/10.1503/jpn.130097.

60. Juma P, Mohamed S, Kyobutungi C. Analysis of Non-communicable Disease Prevention Policies in Kenya. Nairobi: African Population Health Research Center; 2017. https://aphrc.org/wp-content/uploads/2018/10/ANPPA-Kenyareport_final.pdf. Accessed 30 Apr 2020.

61. Kageha E. Mainline. Drug Laws and Human rights in Kenya. 2015. https:// www.hivgaps.org/wp-content/uploads/2015/10/34.-Drug-laws-and-humanrights-in-Kenya-Disharmony-in-the-law-and-training-recommendations-tolaw-enforcement.pdf. Accessed 30 April 2020.

62. World Health Organization. Joint United Nations statement on ending discrimination in health care settings. 2017. https://www.who.int/newsroom/detail/27-06-2017-joint-united-nations-statement-on-endingdiscrimination-in-health-care-settings. Accessed 30 April 2020

63. International Labor Organization. Management of Alcohol and Drug Related Issues in the Workplace. 1996. https://www.ilo.org/wcmsp5/groups/ public/---ed_protect/---protrav/---safework/documents/ normativeinstrument/wcms_107799.pdf. Accessed 20 June 2020.
64. National Authority for the Campaign Against alcohol and Drug Abuse. Guidelines for Developing a Workplace Substance Abuse Prevention Policy. 2018. https://nacada.go.ke/sites/default/files/2019-10/ADA\%20Policy\%2 OGuidelines\%202018.pdf. Accessed 20 June 2020.

65. Ministry of Health. Induction of County Health Management Teams Handbook. 2014.

66. National AIDS and STI's Control Programme. Key Population. 2020. [Internet] https://www.nascop.or.ke/key-population-2/. Accessed 17 July 2020

67. Rhodes T. The becoming of methadone in Kenya: how an intervention's implementation constitutes recovery potential. Soc Sci Med. 2018;201:71-9. https://doi.org/10.1016/.socscimed.2018.02.007.

68. National Authority for the Campaign Against Alcohol and Drug Abuse. Public Education \& Advocacy. 2020. [Internet]. https://nacada.go.ke/publiceducation-advocacy. Accessed 17 July 2020

69. National Authority for the Campaign Against Alcohol and Drug Abuse. Counseling \& Rehabilitation. 2020. [Internet]. https://nacada.go.ke/ counselling-rehabilitation. Accessed 30 Apr 2020.

70. Substance Abuse and Mental Health Services Administration (US); Office of the Surgeon General (US). Facing Addiction in America: The Surgeon General's Report on Alcohol, Drugs, and Health. Washington (DC): US Department of Health and Human Services; 2016. Chapter 6, Health Care Systems And Substance Use Disorders https://wwwncbinlmnihgov/books/ NBK424848/ Accessed 30 April 2020.

71. de Menil VP, Knapp M, McDaid D, Njenga FG. Service use, charge, and access to mental healthcare in a private Kenyan inpatient setting: The effects of insurance. PLos One. 2014;9(3):e90297. https://doi.org/10.1371/ journal.pone.0090297.

72. Suchman L, Hart E, Montagu D. Public-private partnerships in practice: collaborating to improve health finance policy in Ghana and Kenya [published correction appears in health policy plan. 2018 Sep 1;33(7):877]. Health Policy Plan. 2018;33(7):777-85. https://doi.org/10.1093/heapol/czy053.

73. Kelly JF, Yeterian JD. The role of mutual-help groups in extending the framework of treatment. Alcohol Res Health. 2011;33(4):350-5.

74. Alcoholics Anonymous meetings Kenya [Internet]. Available from: AA: https://www.aa-kenya.or.ke/meetings.html. Accessed 20 June 2020.

75. Anderson P, Chisholm D, Fuhr DC. Effectiveness and cost-effectiveness of policies and programmes to reduce the harm caused by alcohol. Lancet. 2009;373(9682):2234-46. https://doi.org/10.1016/S0140-6736(09)60744-3.

76. World Health Organization. Funding mechanisms for the prevention and treatment of alcohol and substance use disorders. 2017. http://www.who. int/substance_abuse/activities/fadab/msb_adab_funding.pdf?ua=1. Accessed 28 April 2020

77. Committee on Prevention, Diagnosis, Treatment, and Management of Substance Use Disorders in the U.S. Armed Forces; Board on the Health of Select Populations; Institute of Medicine. In: O'Brien CP, Oster M, Morden E, editors. Substance Use Disorders in the U.S. Armed Forces. Washington (DC): National Academies Press (US); 2013. Appendix F, Workforce Standards for Substance Use Disorder (SUD) Care. https://www.ncbi.nlm.nih.gov/ books/NBK207291/ Accessed on 30th April 2020.

78. National Authority for Campaign against Alcohol and Drug Abuse [Internet]. https://nacada.go.ke/publications. Accessed 30 April 2020.

79. Kihuba E, Gathara D, Mwinga S, et al. Assessing the ability of health information systems in hospitals to support evidence-informed decisions in Kenya. Glob Health Action. 2014;7:24859. https://doi.org/10.3402/gha.v7. 24859.

80. World Health Organization. Model list of essential medicines. 2019. https:// apps.who.int/iris/bitstream/handle/10665/325771/WHO-MVP-EMP-IAU-2019. 06-eng.pdf?ua=1. Accessed 30 April 2020.

81. Ambale AC, Sinei K, Oluka MN, Amugune B. Accessibility of medicines used in the management of substance use disorders in two hospitals in Nairobi. 2016. https://pdfs.semanticscholar.org/62c1/3aa5d7485e28224a91c3d3e63 fc144a7562c.pdf. Accessed 29 April 2020 (Unpublished).

82. World Health Organization. World Health Organization- Assessment Instrument for Mental health Systems (WHO-AIMS) Version 2.2. 2005. https:// www.who.int/mental_health/publications/who_aims_instrument/en/. Accessed 21 June 2020

\section{Publisher's Note}

Springer Nature remains neutral with regard to jurisdictional claims in published maps and institutional affiliations. 